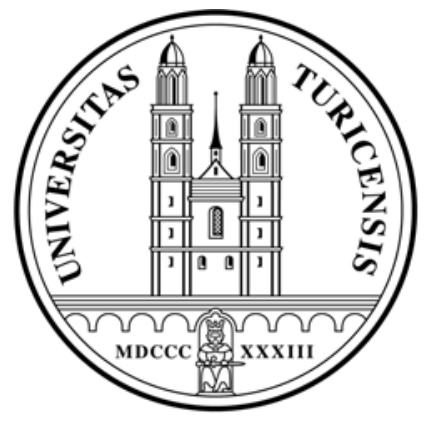

Institute for Empirical Research in Economics

University of Zurich

Working Paper Series

ISSN 1424-0459

Published in: Ram Mudambi, Pietro Navarra and Guiseppe Sobbrio (eds) (2001).

Rules and Reason. Perspectives on Constitutional Poltical Economy.

Cambridge: Cambridge University Press. S. $237-257$

Title: A proposal for Dynamic European Federalism: FOCI

Working Paper No. 56

A Proposal for a Flexible Europe

Bruno S. Frey and Reiner Eichenberger

August 2000 


\title{
A PROPOSAL FOR A FLEXIBLE EUROPE
}

\author{
Bruno S. Frey and Reiner Eichenberger ${ }^{*}$
}

\section{INTRODUCTION}

Entry into the European Union is regulated by three sets of formal requirements ${ }^{1}$ :

- According to the "Copenhagen criteria" new members must have a stable democracy, follow the rule of law, observe appropriate standards of human rights, and must protect minorities;

- They must have a functioning market economy; and most importantly

- The acceding states must agree to the obligations of EU membership which includes adherence to the aims of political and economic union. This means that they have to fully accept the "acquis communautaire". This legal corpus of the EU has by now grown to a large size, involving no less than 16,000 pages of text.

\footnotetext{
${ }^{*}$ Bruno S. Frey is professor of economics at the University of Zurich, Reiner Eichenberger is associate professor of economics at the University of Fribourg.
} 
From the economic point of view, the problems created by the huge differences in income levels between the applying countries (see Carius, Homeyer and Baer 2000) are even more important. This is also true for the five Central and East-European Countries (CEECs), who in the opinion of the European Council are already meeting the requirements mentioned above, and with whom formal accession negotiations have started in March 1998, namely the Czech Republic, Estonia, Hungary, Poland, and Slovenia. They all have dramatically lower per capita incomes than the present EU members. Even Portugal, the poorest present member, has a per capita GNP of $\$ 11,010$, compared to, for instance, Estonia with $\$ 3,360$. The situation is even more extreme for the other five CEECs who applied for membership (Bulgaria, Latvia, Lithuania, Romania and Slovakia). Romania has a per capita income of only $\$ 1,410$, and Bulgaria of $\$ 1,170$.

These economic aspects are matched by the weaknesses of the decision making processes in the EU. Thus, the integration of the CEECs is faced by four important problems:

(1) The current system of income redistribution among the EU countries, undertaken via the Common Agricultural Policy or the Structural Funds, cannot be maintained. It would impose too high a burden on all the present members, including those now benefiting from the redistribution programs.

(2) The large increase in the number of member countries with even more divergent preferences in the population necessitates new decision-making mechanisms in the Council of Ministers and the Commission. Absent such structural changes there is a risk of deadlock or at least of a standstill.

\footnotetext{
${ }^{1}$ See extensively Cameron 1998, Dehousse 1998, Laurent and Maresceau 1998, Wagener and Heiko 1998.
} 
(3) The outer-border problems of the EU do not diminish, but rather accentuate, when the CEECs who apply for membership are forced to accept the whole acquis communautaire. An enlarged EU would be faced with countries such as Ukraina and Belarus with an even less developed economy. The income discrepancies at the new outer-borders would be huge, with the consequent tensions.

(4) The basic problem of the EU, the democracy deficit, is not tackled by enlargement at all. Rather, it is even increased. In a growing EU without fundamental institutional reforms, the negotiation processes among the member countries become more complex and the responsibilities more blurred. Thus, the citizens influence on politics diminishes and the discretionary leeway of the EU decision-making bodies increases. This strengthens not only the citizens' resistance against enlargement of the EU, but also against its deepening.

How will the European Union respond to these challenges? A likely scenario is already partly visible. The negotiations most probably extend over a long period, in any case much longer than desired by the applicants. The formal conditions will be maintained but long adjustment periods will have to be granted. Thus, the CEECs will legally be members of the Union - they will be able to participate in its decision-making - but economically they are far from equal to the other members. The many temporary exceptions to the "acquis communautaire" are due to relate to many different areas. Most importantly, the free movement of labor will likely be blocked by the present members, while the new members will ask for exemptions from the free movement of goods, services, and capital. The challenges will therefore be solved on the legal level only while the underlying economic problems of integration will remain unsolved. Most probably, the political structure of the EU will not be fundamentally changed, but only the weights of the countries in the decision procedures will be somewhat adjusted, and the requirements of unanimity and qualified majorities will be somewhat softened. The discussion on the democracy deficit, finally, is rather crowded out by the strong focus on enlargement. 
As long as the enlargement process is going on, the resources needed for reforms are bound in this process and it is unlikely that the democratic institutions and, thus, the citizens' political influence are effectively strengthened. On the whole, this scenario suggests that the European Union proceeds by "muddling through" instead of squarely facing the problems of enlarged membership.

This paper suggests a basically different approach guided by economic principles. While it strongly deviates from rather haphazard muddling through, our proposal is not utopian at all but is immediately applicable to EU enlargement.

Our basic idea is that there should be the possibility of partial entry into the European Union rather than the all or none decision to accept the whole acquis communautaire at one stroke. Following our proposal, the CEECs should have the option of entering with respect to functions where they expect positive net benefits, and to stay out with respect to functions where this is not the case. Potential entrants should thus be able to act according to their willingness to pay, or implicit demand curve, with respect to the various relevant functions. In order to enable such partial entry, a new type of jurisdictions called FOCJ is proposed between the EU, the CEECs, and beyond. These functional jurisdictions are not to be imposed from above but should emerge as the result of the voluntary negotiations between the new partners. To the extent the CEECs develop (partly because of the existence of these flexible partnerships) an increasing number of such FOCJ with different members and functions will arise so that an ever closer integration will take place. With FOCJ, variable geometry is a desirable feature of integration rather than a shortcoming. It goes much beyond the proposal for a multi-speed integration of some "chosen" countries into a "core Europe" (as recently proposed by the German foreign minister Fischer), or the special cases of the treaties of Schengen and of the Economic and Monetary Union EMU which not all EU member countries need to join. 


\section{THE PROPOSAL: FOCJ}

The jurisdictions here proposed to facilitate the integration of the CEECs with the European Union have four essential characteristics. FOCJ is the acronym for:

- Functional $(F)$, i.e. the new jurisdictions extend over areas defined by the tasks to be fulfilled;

- Overlapping $(O)$, i.e. in line with the many different tasks (functions) there are corresponding governmental units straddling areas belonging to the various CEECs and the $\mathrm{EU}$

- Competing $(C)$, i.e. communities in the CEECs and the EU may choose to which functional jurisdictions they want to belong. Moreover, these jurisdictions are governed by democratic mechanisms. They may be based on the representation of voters or the voters may express their preferences directly via initiatives and referenda;

- Jurisdictions $(J)$, i.e. the units straddling the CEECs and the EU are governmental in the sense that they have enforcement power and can, in particular, levy taxes.

FOCJ are based on theoretical propositions advanced in the economic theory of federalism. They nevertheless form a governmental system completely different to the one suggested in that literature. While the economic theory of federalism analyzes the behavior of given political units at the different levels of government, FOCJ emerge in response to the geography of the problems of integration. ${ }^{2}$

\footnotetext{
${ }^{2}$ The concept of FOCJ is extensively discussed in Frey and Eichenberger (1999). Similar ideas can already been found in by Montesquieu (1749). Burnheim (1985) mentions similar elements. In the economics literature a
} 
The four elements of FOCJ are now related to economic theory as well as to existing federal institutions, pointing out both similarities and differences to existing concepts.

\section{A. Functions}

A particular public service, which benefits a certain geographical area, should be financed by the people living in that area, i.e. there should be no spill-overs. The different governmental units can cater for regional differences in the populations' preferences or, more precisely, to its demands. To minimize cost, these units have to exploit economies of scale in production. As the latter may strongly differ between functions (e.g., between schools, police, environmental policy or defense), there is an additional reason for uni-functional (or fewfunctional ${ }^{3}$ ) governmental units of different sizes. This is the central idea of "fiscal equivalence" as proposed by Olson (1969) and Oates (1972). This endogeneity of the size of governmental units constitutes an essential part of FOCJ. However, fiscal equivalence theory has been little concerned with decision-making within functional units. The supply process is either left unspecified or it is assumed that the mobility of persons (and of firms, a fact rarely mentioned) automatically induces these units to cater for individual preferences.

\section{B. Overlaps}

FOCJ may overlap in two respects: (i) FOCJ catering to different functions may overlap; (ii) two or more FOCJ catering even for the same function may geographically intersect (e.g., a multitude of school FOCJ may exist in the same geographical area). A political unit normally

related concept has been pioneered by Tullock (1994), who calls it 'sociological federalism'. Casella and Frey (1992) discuss the concept and refer to relevant literature.

\footnotetext{
${ }^{3}$ If there are strong economies of scope dominating the economies of scale, a FOCUS (which is taken to be the singular of FOCJ) may cover more than one function.
} 
belongs to various FOCJ at the same time. FOCJ need not be physically contiguous, and they need not have a monopoly over a certain area of land. Thus, this concept completely differs from archaic nationalism with its fighting over pieces of land. It also breaks with the notion of federalist theory that units at the same level may not overlap. On the other hand, in this respect it is similar to Buchanan's (1965) "clubs" which may intersect.

\section{Competition}

The heads of FOCJ are induced to conform closely to their members' preferences by two mechanisms: while the member units' possibilities to exit mimics market competition (Hirschman 1970), the citizens' right to vote establishes political competition (see Mueller 1989). It should be noted that in FOCJ exit does not depend on migration. The citizens of a political unit can discontinue membership in a particular FOCUS and perhaps enter a new one without changing their location. Moreover, exit is not restricted to political units as a whole; parts of them may also exercise this option.

Exit of member units in the form of secession has been suggested as an important ingredient for a future European constitution (Buchanan 1991, European Constitutional Group 1993). The right to secede stands in stark contrast to the prevailing concepts of nation states and federations where this is strictly forbidden and often prevented by force. Current European treaties do not provide for the secession of a nation from the European Union, and a fortiori for part of a nation. However, exit in a system of FOCJ is a much broader concept than secession. While secession in the traditional sense is always total, i.e. refers to all functions, exit with FOCJ is partial, i.e. refers to only one or few functions.

For FOCJ to establish competition between governments, exit should be as unrestrained as possible but if a negative external cost is imposed on the remaining members, an exit price 
has to be levied. Similarly, entry need not necessarily be free. As for individuals in Buchanantype clubs, a price may be asked for joining a particular FOCUS. The existing members of the particular FOCUS have to democratically decide whether a new member pays an adequate entry price and thus is welcome. As long as competition among FOCJ is not strong enough to enforce efficient pricing, the entry and exit prices have to be monitored by an independent body.

Competition also needs to be furthered by political institutions, as the exit option does not suffice to induce governments to act efficiently. The citizens should directly elect the persons managing the FOCJ, and may even be given the right to initiate popular referenda on specific issues. These democratic institutions are known to raise efficiency in the sense of caring well for individual preferences (for elections, see Downs 1957, Mueller 1989; for popular referenda, see Frey 1994, Frey and Stutzer 2000, Eichenberger 1999).

\section{Jurisdictions}

A FOCUS is a democratic governmental jurisdiction with authority over its citizens, including the power to tax. The lowest political unit (normally the community) is a member, and all corresponding citizens automatically become citizens of the FOCJ to which their community belongs. They have to carry the taxes to finance the public services provided by a particular FOCUS.

\section{FOCJ AND EU-ENLARGEMENT}

\section{A. The General Point}

FOCJ allow for differentiated, tailor-made integration. Thus, they contrast strongly with the acquis communautaire which stands for equalized integration. With FOCJ, countries and 
regions can search for cooperation in those functions in which they have a real demand for cooperation, and they are not forced into cooperation with respect to functions on which they want to stand alone. However, FOCJ do not lead to less integration than the acquis communautaire for three reasons. First, FOCJ decrease the price of integration to the citizens, and, thus, increase the demand for integration as they make integration more efficient and the citizens democratic influence to grow. Second, thank to FOCJ integration of the CEECs is no more a question of "all or nothing". The countries which are not able to make it quickly to the acquis communautaire can be integrated more closely with FOCJ than without. Third, a FOCUS may aim at stronger integration with respect to its specific function than the acquis.

Of course, differentiated integration is not a totally new concept. Today's standard procedure of integration of new member countries also entails some differentiation as the countries are granted different adaptation periods. These, however, are only looked at as temporary exceptions and unwelcome deviations from the current normal of the acquis. They do neither allow for stronger integration with respect to some functions, nor do they give the new entrants the right to search for different degrees of integration with a special selection of today's members. Moreover, the concept of FOCJ goes much beyond a partial integration via treaties. It provides for a common government composed of all the members. The extended rights of political codetermination strengthen identification and provide the basis for solidarity among the members.

\section{B. Multiple Opportunities}

Three kinds of FOCJ can be distinguished:

(a) FOCJ formed by communes and regions of some EU-member and non-member states. This is a new form of cross border cooperation. A pertinent example refers to local 
environmental degradation, say water pollution. One or several communes of, e.g., Hungary, Slovenia and Austria may form an environmental FOCUS. The government of the FOCUS will be elected by the citizens of all the communes involved. The FOCUS is responsible for water quality in the area, will set the standards best meeting the preferences of all the citizens and will impose the taxes necessary to reach these goals. The Hungarian and Slovenian communes can therewith adopt an environmental standard higher than that generally obtaining in the rest of their nations. Such an institutional arrangement is also advantageous for the respective Austrian communes because of the negative spillovers connected with Hungarian and Slovenian emissions.

(b) FOCJ formed by some EU-member and non-member states. An example is the perceived thread of cheap labor flowing in great numbers into Germany. With present arrangements, the German government put under pressure by its trade unions is likely to block a full scale entry of Poland into the EU. Although other present EU members are much less concerned about this presumed danger, Germany will push through very long protection against such cheap labor immigrating the EU. Under the regime here suggested, the other members of the EU and Poland can integrate their labor markets in a FOCUS. This allows Poland and these other countries to exploit their international comparative advantage. Poland supplies its relatively abundant labor, and the others their abundant real and human capital. The members of the labor mobility FOCUS experience a welfare gain compared to the Germans inhibiting full integration according to the acquis communautaire.

(c) FOCJ formed by all the EU-member and non-member states. The CEECs and the EU have a common interest in fighting against transnational mafia-type activities. Today, this problem is approached in a purely technocratic way via EUROPOL and INTERPOL, often with very limited success. A police FOCUS comprising nations affected brings about a more efficient anti-mafia policy because governance and taxation are matched. 
The FOCUS allows deploying the police resources in the areas where they are most effectively used. In contrast, the EU does not know any joint police forces, not even for special purposes. Such a police FOCUS would thus go beyond the integration now existing in the EU. Obviously, such a FOCUS can also partially integrate countries beyond the CEECs, Russia or North-African countries being examples.

\section{Meeting the Challenges}

By making use of the concept of FOCJ, the four main challenges faced by an enlarging EU can be successfully addressed.

(1) Income redistribution. FOCJ reduce the problems connected with redistribution via two channels. First, the demand for receiving subsidies by the today's members of the EU is reduced because with FOCJ it is feasible to cooperate mainly with respect to those functions which yield particular high benefits of cooperation. The CEECs are not forced to compromise on functions from which they do not profit much, or even lose, when accepting the acquis communautaire. Therefore they need less compensation. Second, it is likely that the full entry of some or all CEECs is blocked by those members which would lose from a new targeting of redistributive flows. With FOCJ, instead, a particular CEEC and the EU can establish a redistribution FOCUS acceptable to all present EU members.

(2) EU decision-making structure. Those present EU-members which do not agree with the partial admission of one or several CEECs can opt out instead of having to use their veto power. Thus, the presently existing decision-making mechanism in the EU need not be changed. 
(3) Outer-border problems. The use of FOCJ allows a differentiated expansion of the EU instead of a strict rupture towards non-EU countries. This is achieved in two ways: First, a CEEC may enter EU partially, i.e. with respect to some functions, only. Second, the CEECs as well as EU member countries and may establish FOCJ with countries which are not considered as prospective members of the EU (such as Ukraine, Belarus, and Russia).

(4) Democracy deficit. The FOCJ established are based on democratic principles and therefore overcome the democracy deficit widely attributed to the EU.

\section{EVALUATING FOCJ}

FOCJ compare favorably to the traditional form of integration as undertaken in the EU. One aspect concerns the governments' incentives and possibilities to satisfy heterogeneous preferences of individuals. Due to the concentration on one functional area, the citizens of a particular FOCUS have better information on its activity, and are in a better position to compare its performance to other governments. As many benefits and costs extend over a quite limited geographic area, many FOCJ are likely to be small. The strengthened exit option is also an important means to make one's preferences known to governmental suppliers.

On the other hand, FOCJ are able to provide public services at low cost because they are formed in order to minimize interjurisdictional spillovers and to exploit economies of scale. When the benefits of a specific activity indivisibly extend over large areas, and there are decreasing cost, the corresponding optimal FOCUS may straddle many communities of CEEC and EU countries. It may also be envisaged that several nations establish FOCJ. Such FOCJ then resemble the institutions of closer integration in the form of the treaties of Schengen and of the EMU. They differ, however, as FOCJ are democratic and impose their own taxes. 
The threat of dissatisfied member units to exit the FOCUS, and the benefit of new units joining, gives an incentive to take individual preferences into account and to provide the public services efficiently. Quite another advantage of FOCJ is that they open up the politicians' cartel (“classe politique”) to functionally competent outsiders. While all-purpose jurisdictions attract politicians and administrators with broad and non-specialized knowledge, in FOCJ, persons with a well-grounded knowledge in a particular functional area (say university education or health care) are successful.

A web composed of FOCJ certainly affects the role of the nation within both CEECs and the EU. Existing nations will certainly lose functions. On the other hand, the scheme does not purport to do away with nations but allows for multi-national as well as small scale alternatives where they are desired by the citizens. Nation states subsist in so far as they provide functions efficiently according to the voters' preferences.

In two countries functional, overlapping and competing jurisdictions exist to some degree (see Frey and Eichenberger 1999, p. 49-53). They do not in all cases meet all the requirements of FOCJ specified above but they nevertheless show that democratic functional jurisdictions are viable. In the United States, single-purpose governments in the form of special districts play a significant role. In Switzerland, many cantons have a structure of overlapping and competing functional jurisdictions that share many features of FOCJ. The example from Switzerland which is generally considered to be a well organized and administered country - suggests that a multiplicity of functional jurisdictions under democratic control is not a theorist's wishful thinking but has worked well in reality. 


\section{COMPARISON TO OTHER PROPOSALS}

FOCJ differ in many crucial respects from other proposals for a future European constitution. One of the most prominent is Buchanan (1991) who stresses individual nation's right to secede but, somewhat surprisingly, does not build on Buchanan-type clubs. The European Constitutional Group (1993) focuses on the example of the American constitution, and presents constructivist proposals with respect to the houses of parliament and the respective voting weights of the various countries. Overlapping jurisdictions and referenda are not allowed for, and the exit option is strongly restricted. Other economics scholars (e.g., Blöchliger and R. L. Frey 1992, Schneider 1992) suggest a strengthening of federalism in the traditional sense (i.e. with multi-purpose federal units) but do not envisage overlapping jurisdictions. The report by the Centre for Economic Policy Research $(1993,1995)$ shortly raises the idea of overlapping, not geographically based jurisdictions but it is not institutionally worked out, the need for a democratic organization and the power to tax is not acknowledged, and the idea is not applied to the problem of integration into the European Union.

FOCJ are also quite different from the regions envisaged in existing European treaties and institutions (see, e.g., Adonis and Jones 1991). A major difference is that FOCJ emerge from below while the 'European regions' tend to be established from above. Moreover, their existence strongly depends on the subsidies flowing from the European Union and the nation states (Sharpe 1993). In contrast, the concept of FOCJ corresponds to Hayek's (1960) nonconstructivist process view. It cannot a priori be determined from outside and from above which FOCJ will be efficient in the future. This must be left to the competitive democratic process taking place at the level of potential member units. The central European constitution must only make sure that no other government units, in particular the nations, obstruct the emergence of FOCJ. In contrast to Hayek, however, the scheme allows for a (closely 
restricted) set of central regulations, in particular the Copenhagen criteria mentioned at the beginning of this paper.

"Subsidiarity" as proclaimed in the Maastricht Treaty is generally recognized to be more a vague goal than a concept with content (see, e.g., Centre for Economic Policy Research 1993: 19-23). Even if subsidiarity were taken seriously, it would not lead to a real federal structure because many (actual or prospective) members of the European Union are essentially unitary states without federal subunits of significant competence (examples are the Netherlands, France or Sweden). The "regions" existing in the European Union (examples are Galicia and Cataluña in Spain, or South Tyrol and Sicily in Italy) are far from being units with significant autonomous functional and fiscal competencies.

The Council of Ministers is a European decision making institution based on federal principles (but nations only are represented) and organized according to functional principles (or at least according to the corresponding administrative units). However, this Council is only indirectly democratic (the ministers are members of governments which are democratically legitimized by the representative system) and the deliberations are not public. Exit from the European Union is not formally regulated, and exceptions to specific aspects of agreements reached (as in the Maastricht Treaty concerning the European Monetary Union and the Protocol on Social Policy, or in the Schengen Treaty concerning the free movement of persons) are granted reluctantly. Indeed, they are seen as damaging the "spirit of Europe". Whether differential degrees of European integration are framed as models of "variable geometry", "multi-track", "multi-speed", "two-tier", "hard core", "concentric circles", or as "Europe à la carte", it always evokes fierce opposition. In a system of FOCJ, in contrast, functional units not covering everyone are taken as a welcome expression of heterogeneous demands among European citizens. 


\section{CONCLUDING REMARKS}

FOCJ provide a feasible institutional procedure to integrate the Central and East-European Countries into the European Union. At present, the politicians governing the European Union insist that these nations fully accept the "acquis communautaire" though their economic and institutional development differs drastically from those of the present member states. FOCJ allow for partial integration on the basis of economic efficiency and democratic rules. The functional jurisdictions proposed to straddle areas of the CEECs and the European Union may not only overcome the huge economic and financial obstacles but may also introduce a democratic element which is most welcome in the face of the much discussed "democratic deficit" attributed to the EU.

FOCJ may also be used to straddle communes situated in two or more member states of the European Union. Such FOCJ would make a substantial contribution to the coming together of Europe at a level directly benefiting the citizens. Such jurisdictions would certainly strongly contribute to the emergence of a "European spirit".

Decentralized, overlapping political units have been an important feature of European history. Many scholars attribute the rise of Europe to this diversity and competition of governmental units, which fostered technical, economic and artistic innovation (see, e.g., Hayek 1960, Jones 1981, Rosenberg and Birdzell 1986, Weede 1993). A fully fledged adaptation of the model of Functional, Overlapping, and Competing Jurisdictions would lead to a federal net of units with widely different tasks and geographical extensions. If based on FOCJ, a United Europe would no longer be associated with a centralized bureaucratic body but with variety and, thus, the basis of the success of Europe. 


\section{References}

Adonis, Andrew and Stuart Jones (1991). Subsidiarity and the European Community's Constitutional Future. Staatswissenschaft und Staatspraxis 2 (2): 179-196.

Blöchlinger, Hansjörg and René L. Frey (1992). Der schweizerische Föderalismus: Ein Modell für den institutionellen Aufbau der Europäischen Union. Aussenwirtschaft 47: 515548.

Buchanan, James M. (1965). An Economic Theory of Clubs. Economica 32 (February): 1-14.

Buchanan, James M. (1991). An American Perspective on Europe's Constitutional Opportunity. Cato Journal 10 (3): 619-629.

Burnheim, John (1985). Is Democracy Possible?: The Alternative to Electoral Politics. Cambridge: Polity Press.

Cameron, Fraser (1998). Preparing for enlargement: Policy and Institutional Reform in the EU. Brussels: European Commission Directorate General IA.

Carius, Alexander, Ingmar von Hohmeyer and Stefani Bär (2000). The Eastern Enlargement of the European Union and Environmental Policy: Challenges, Expectations, Speed and Flexibility. In: Katharia Holzinger and Peter Knoepfel (eds.): Environmental Policy in a European Union of Variable Geometry? The Challenge of the Next Enlargement. Basel: Helbing und Lichtenhahn: 141-180.

Casella, Alessandra and Bruno S. Frey (1992). Federalism and Clubs: Towards an Economic Theory of Overlapping Political Jurisdictions. European Economic Review 36: 639-646. 
Centre for Economic Policy Research (CEPR) (1993). Making Sense of Subsidiarity: How Much Centralization for Europe? London: CEPR.

Centre for Economic Policy Research (CEPR) (1995). Flexible Integration. Towards a More Effective and Democratic Europe. London: CEPR.

Dehousse, Renaud (ed.) (1998). An Ever Larger Union? The Eastern Enlargement in Perspective. Baden-Baden: Nomos.

Downs, Anthony (1957). An Economic Theory of Democracy. New York: Harper and Row.

Eichenberger, Reiner (1999). Mit direkter Demokratie zu besserer Wirtschafts- und Finanzpolitik: Theorie und Empirie. In: Hans Herbert von Arnim, Adäquate Institutionen: Voraussetzungen für "gute" und bürgernahe Politik? Berlin: Duncker \& Humblot: 259288.

European Constitutional Group (1993). A European Constitutional Settlement. (Draft) London.

Frey, Bruno S. (1994). Direct Democracy: Politico-Economic Lessons from Swiss Experience. American Economic Review 84 (2): 338-348.

Frey, Bruno S. and Reiner Eichenberger (1999). The New Democratic Federalism for Europe: Functional Overlapping and Competing Jurisdictions. Cheltenham: Edward Elgar.

Frey, Bruno S. and Alois Stutzer (2000). Happiness, Economy and Institutions. Economic Journal (forthcoming)

Hayek, Friedrich A. von (1960). The Constitution of Liberty. London: Routledge. 
Hirschman, Albert O. (1970). Exit, Voice and Loyality. Cambridge, MA: Harvard University Press.

Jones, Eric L. (1981). The European Miracle. Cambridge, U.K.: Cambridge University Press.

Laurent, Pierre-Henry and Marc Maresceau (eds.) (1998). The State of the European Union: Deepening and Widening. Boulder and London: Lynne Riemer.

Montesquieu, Charles Louis (1749). De l'esprit des lois. Paris: Garnier.

Mueller, Dennis C. (1989). Public Choice II. Cambridge: Cambridge University Press.

Oates, Wallace E. (1972). Fiscal Federalism. New York: Harcourt Brace Jovanovich.

Olson, Mancur (1969). The Principle of "Fiscal Equivalence": The Division of Responsibilities among Different Levels of Government. American Economic Review 59 (2): 479-487.

Rosenberg, Nathan and L. E. Birdzell (1986). How the West Grew Rich. The Economic Transformation of the Industrial World. London: I.B. Tauris.

Schneider, Friedrich (1992). The Federal and Fiscal Structures of Representative and Direct Democracies as Models for a European Federal Union: Some Ideas using the Public Choice Approach. Journal des Economistes et des Etudes Humaines 3: 403-437.

Sharpe, L. J. (ed.) (1993). The Rise of Modern Government in Europe. London: Sage.

Tullock, Gordon (1994). The New Federalist. Vancouver: Fraser Institute. 
Wagener, Hans-Jürgen and Heiko Fritz (eds.) (1998). Aspekte der EU-Osterweiterung. Bon: Dietz.

Weede, E. (1993). The Impact of Interstate Conflict on Revolutionary Change and Individual Freedom. Kyklos 46: 473-495. 